\title{
PERBEDAAN INDIVIDU SEBAGAI FAKTOR PENYEBAB STRES KERJA PADA TENAGA KESEHATAN AKIBAT PANDEMI COVID-19: NARRATIVE LITERATURE REVIEW
}

\section{Individual Differences as a Work Stress Factors Causing on Healthcare Personnel Due to the Covid-19 Pandemic: A Narrative Literature Review}

\author{
Tashya Angelie Tamara*, Ratna Dwi Wulandari \\ Program Studi Ilmu Kesehatan Masyarakat Fakultas Kesehatan Masyarakat \\ Universitas Airlangga, Jl. Mulyorejo No. 4760115 Surabaya, Jawa Timur, Indonesia \\ *email: tashya.angelie.tamara-2016@fkm.unair.ac.id
}

\begin{abstract}
Coronavirus disease known as COVID-19, which has claimed millions of lives worldwide. Healthcare personnel as someone who plays an important role in improving the health status of the community are required to be able to provide optimal services for the community. The pressure felt by healthcare personnel due to the COVID-19 pandemic can affect the mental health of healthcare personnel, one of them which can cause work stress. Stress can occur, one of which is influenced by the way individuals respond to the pressure they get at work. Individuals who can control pressure from outside properly can avoid stress. The purpose of this study was to analyze individual differences as a factor causing work stress in healthcare personnel due to the COVID-19 pandemic. This type of research is a narrative literature review with a journal population of 113 articles. After, going through the screening process, quality assessment, data extraction, and conformity with the study inclusion criteria, 16 articles were obtained as reference articles that could be used in this study. The results showed that 4 different individual factors caused work stress to health workers due to the COVID-19 pandemic, namely negative perceptions about COVID-19, lack of work experience, worry about COVID-19, such as worrying about being infected with COVID-19 and worrying about transmitting COVID-19 to the closest relatives/family, lastly in the form of low social support from family and colleagues. The government and agencies are expected to pay attention to the mental health of healthcare personnel. Also, healthcare personnel are expected to continue to do positive things that can build morale during the COVID-19 pandemic.
\end{abstract}

Keywords: Stress, individual differences, healthcare personnel, COVID-19

\begin{abstract}
Abstrak
Coronavirus disease yang dikenal dengan sebutan COVID-19 telah merenggut jutaan nyawa di seluruh dunia. Tenaga kesehatan sebagai seseorang yang berperan penting dalam meningkatkan derajat kesehatan masyarakat dituntut untuk bisa melakukan pelayanan terpadu yang optimal bagi masyarakat. Tekanan atau tuntutan yang dirasakan oleh tenaga kesehatan akibat pandemi COVID-19 dapat mempengaruhi kesehatan mental tenaga kesehatan, salah satunya dapat menyebabkan stres kerja. Stres dapat terjadi salah satunya dipengaruhi oleh cara individu dalam merespon tekanan yang diperoleh di tempat kerjanya. Individu yang dapat mengendalikan tekanan dari luar dengan baik dapat terhindar dari stres. Tujuan dari penelitian ini adalah untuk menganalisis perbedaan individu sebagai faktor penyebab stres kerja pada tenaga kesehatan akibat pandemi COVID-19. Jenis penelitian ini berupa narrative literature review dengan populasi jurnal sebanyak 113 artikel. Setelah, melalui proses screening, penilaian kualitas, ekstrasi data, dan kesesuaian dengan kriteria inklusi penelitian, maka diperoleh 16 artikel sebagai artikel rujukan yang dapat digunakan dalam penelitian ini. Hasil penelitian menunjukan terdapat 4 faktor perbedaan individu yang menyebabkan stres kerja pada tenaga kesehatan akibat pandemi COVID-19, yaitu persepsi negatif tentang COVID-19, pengalaman kerja yang kurang, rasa
\end{abstract}


khawatir tentang COVID-19, seperti khawatir terinfeksi COVID-19 dan khawatir dapat menularkan COVID-19 pada kerabat/ keluarga terdekat, terakhir berupa dukungan sosial dari keluarga maupun rekan kerja yang rendah.Pemerintahan dan instansi terkait diharapkan dapat memperhatikan kesehatan mental tenaga kesehatan. Selain itu, tenaga kesehatan diharapkan tetap melakukan hal-hal positif yang dapat membangun semangat kerja selama masa pandemi COVID-19.

Kata Kunci: Stres, perbedaan individu, tenaga kesehatan, COVID-19

\section{PENDAHULUAN}

Virus global menular yang kemudian dikenal dengan sebutan Coronavirus Disease 2019 (COVID-19) telah menjadi ancaman bagi kehidupan manusia. Virus Corona telah menyebar pada 218 negara serta menyebabkan lebih dari 43.000 .000 orang menderita sakit dan telah merenggut lebih dari 1.000 .000 nyawa tanpa ada tanda penurunan jumlah kasus maupun jumlah kematian (WHO, 2020). Virus ini berasal dari keluarga Coronaviridae yang memiliki kemiripan sebesar $80 \%$ dengan virus SARS (Servere Acute Respiratory Syndrom) (Shereen et al., 2020). Tingkat kematian yang disebabkan oleh virus Corona di Provinsi Hubei, China mencapai $2.8 \%$ dan $0.24 \%$ per Februari 2020 (Liu et al., 2020).

Tenaga kesehatan sebagai seseorang yang mengabdikan diri di bidang kesehatan bertanggung jawab untuk mengupayakan kesehatan terpadu dalam rangka meningkatkan derajat kesehatan masyarakat melalui upaya promotif, preventif, kuratif, dan rehabilitatif (Presiden RI, 2014). Tenaga kesehatan disetiap negara telah mengupayakan berbagai macam tindakan medis untuk mengontrol transmisi virus dan untuk mengobati pasien COVID-19. Terhitung lebih dari 42.000 tenaga kesehatan di China, seperti dokter, perawat, teknisi, dan ahli kesehatan masyarakat dari berbagai provinsi dikirim ke Provinsi Hubei, China untuk membantu penanganan COVID-19 (National Health Commission of the People's Republic China, 2020). Situasi yang serba tidak pasti dan tidak mudah diprediksi seperti saat ini, cenderung meningkatkan risiko gangguan kesehatan mental seperti stres, trauma, depresi, gangguan kecemasan, bahkan keinginan untuk bunuh diri (Greenberg et al., 2020)

Tenaga kesehatan jika dibandingkan dengan populasi secara umum, mengalami berbagai macam tekanan akibat COVID-19 yang disebabkan oleh beragam alasan seperti, tenaga kesehatan harus melakukan kontak langsung dengan pasien terindikasi/ positif COVID-19, berisiko terkena infeksi yang tinggi, alat pelindung diri (APD) yang tidak memadai, kehilangan kontrol akan penyakit, kurangnya pengalaman dalam menangani penyakit, meningkatnya beban kerja, adanya umpan balik negatif dari pasien, stigma yang diterima dari masyarakat, perubahan gaya hidup, karantina, dan kurangnya dukungan sosial dari keluarga (Que et al., 2020)

Menurut Robbins \& Judge (2013) suatu survei telah dilakukan pada 7.807 pekerja dan sebanyak $26 \%$ pekerja menjawab stressor terbesar adalah pekerjaannya. Faktor penyebab stres kerja dibagi menjadi tiga yaitu, faktor lingkungan, faktor perbedaan individu, dan faktor organisasi. Perbedaan individu dikaitkan dengan kemampuan individu dalam menangani stres karena terdapat individu yang mampu menangani stres dengan baik, sementara yang lain merasa kewalahan akibat stres. Faktor perbedaan individu terdiri dari persepsi, pengalaman kerja, dukungan sosial, dan kepribadian (Robbins \& Judge, 2013).

Hasil pencarian literatur menunjukan sebanyak $18 \%$ artikel yang ditemukan membahas mengenai faktor perbedaan individu sebagai penyebab stres kerja pada tenaga kesehatan akibat pandemi COVID-19. Penelitian terdahulu mengenai perbedaan individu yang dapat menyebabkan stres kerja akibat pandemi berupa timbulnya perasaan khawatir yang dialami oleh tenaga kesehatan selama wabah virus SARS berlangsung (Maunder, 2004). Selain itu, dilaporkan sebanyak $20 \%$ tenaga kesehatan merasa tersingkirkan dilingkungan tempat tinggalnya dan sebanyak $15 \%$ tenaga kesehatan tidak pulang ke rumah selama wabah SARS berlangsung karena merasa khawatir dapat menginfeksi kerabat (Bai et al., 2004).

Perasaan khawatir terhadap persebaran virus, dukungan sosial yang rendah, dan persepsi negatif terkait COVID-19 telah dirasakan oleh tenaga kesehatan akibat pandemi COVID-19 melanda dunia. Pengalaman kerja juga menjadi salah satu vaiabel faktor penyebab stres kerja yang dapat mempengaruhi kinerja masingmasing individu. Individu yang memiliki sikap positif atau kontrol diri yang baik dapat 
mengurangi tingkat stres selama wabah berlangsung (Khalid et al., 2016). Namun, jumlah kasus COVID-19 yang terus meningkat diikuti dengan meningkatnya kebutuhan sumber daya kesehatan membuat tenaga kesehatan merasa tertekan dan mengalami kesulitan yang lebih besar (Catton, 2020). Melalui penelitian ini akan dilakukan analisis perbedaan individu sebagai faktor penyebab stres kerja pada tenaga kesehatan akibat pandemi COVID-19.

\section{METODE PENELITIAN}

Penelitian ini termasuk dalam jenis penelitian narrative literature review (Green et al., 2006). Topik penelitian yang dibahas berupa perbedaan individu sebagai faktor penyebab stres kerja pada tenaga kesehatan akibat pandemi COVID-19. Pengumpulan data sekunder bersumber pada electronic database, yaitu PubMed, Google Scholar, dan Science Direct dengan mencantumkan kata kunci yang sesuai dengan kriteria inklusi penelitian. Pencarian artikel/ jurnal menggunakan kata kunci berupa "stress (or stress, psychological), health care workers (or helath personnel), dan COVID-19".

Kriteria eksklusi artikel berupa artikel/ jurnal yang membahas masalah kesehatan mental lain selain stres pada tenaga kesehatan akibat pandemi COVID-19. Berikut merupakan kriteria inklusi aertikel :

a. Artikel yang membahas mengenai perbedaan individu sebagai faktor penyebab stres kerja pada tenaga kesehatan akibat pandemi COVID-19.

b. Artikel tersedia dalam Bahasa Inggris.

c. Artikel terbitan bulan Januari - Oktober 2020.

d. Artikel tersedia dalam full text.

Teknik analisis data menggunakan pendekatan thematic analaysis, yaitu suatu proedur interpretatif dengan memberikan pendapat/ pandangan untuk menemukan pola dalam suatu data serta mencoba untuk menjelaskan terkait fenomena yang dikaji (Smith \& Firth, 2011)

\section{HASIL DAN PEMBAHASAN}

\section{Hasil Penelitian}

Proses pengumpulan artikel/ jurnal terpilih akan divisualisasikan pada Gambar 1 . Hasil 16 artikel/ jurnal yang terpilih akan dirinci pada Tabel 1 untuk mengetahui perbedaan individu sebagai faktor penyebab stres pada tenaga kesehatan.

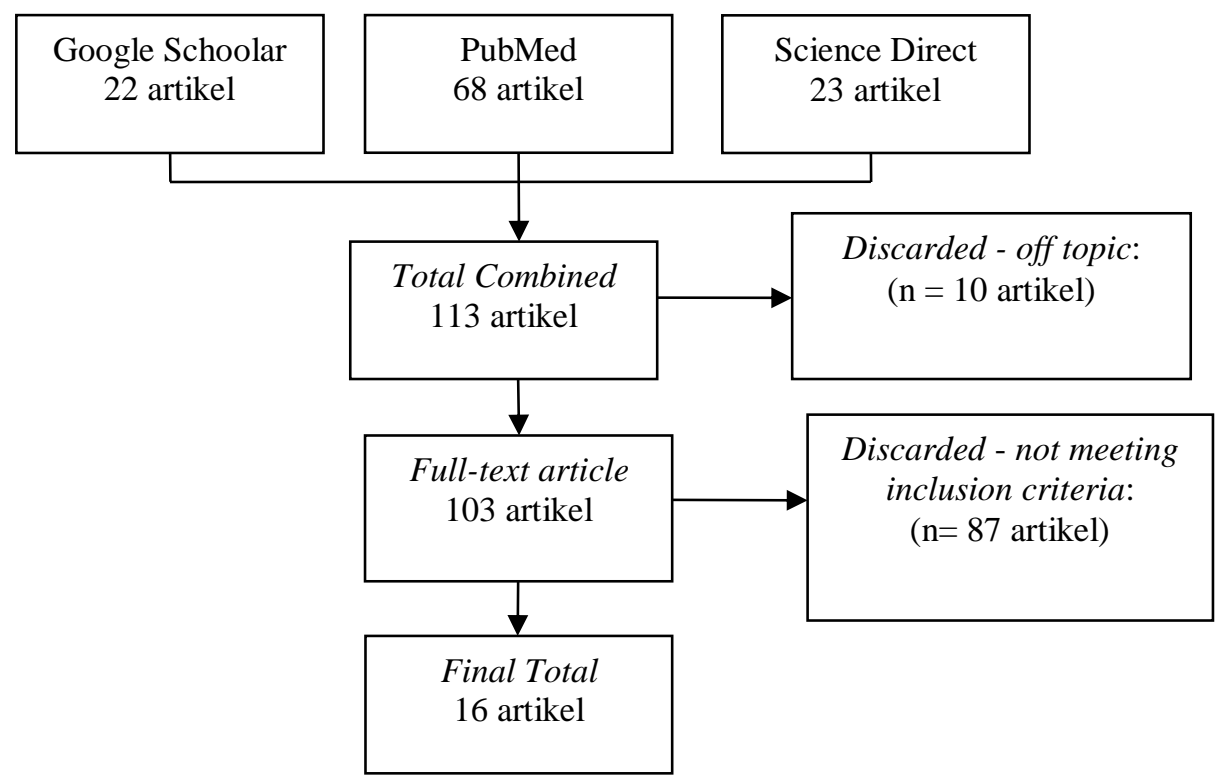

Gambar 1. Tahap Pengumpulan Data Referensi 
Tabel 1. Matrix Literature Review

$\begin{array}{cccc}\text { No. Judul, Peneliti, dan } & \text { Desain } & \text { Faktor penyebab } & \text { Hasil } \\ \text { Tahun } & \text { Penelitian, } & \text { stres } \\ & \begin{array}{c}\text { Populasi, dan } \\ \text { sampling }\end{array} & & \\ & & \end{array}$
Chinese nurses to Sectional support Wuhan $\mathrm{N}=$ fighting against responden

Cross- Perbedaan

individu: dukungan

210 keluarga dan

Covid-19 Epidemic $\mathrm{S}=180$ perawat

(China) Mo, et.all., dari Guaxi yang 2020

dikirim ke Wuhan 2. Covid-19 in Wuhan:
Immediate

Psychological

Impact on 5062

Health Workers

(China) Zhu Z., et all., 2020

3. Psychological Impact of Healthcare Workers in China during COVID-19 Pneumonia Epidemic : A Multi-Center Cross-Sectional

Survey Investigation (China) Xiao Xiao, et all., 2020

Studi CrossSectional $\mathrm{N}=6.568$ kekhawatiran terkait COVID-19.

responden $S=5.062$ tenaga kesehatan di Rumah Tongji

Studi Sakit CrossSectional $\mathrm{S}=958$ responden (dari 26 Provinsi di China), 705 nakes di Wuhan, 140 nakes di Hubei, dan 113 nakes diluar Hubei

4. Mental Health

Outcomes Among

Frontline and

Second-Line Health

Care Workers

During the

Coronavirus Disease 2019 (COVID-19) Pandemic Italy (Italia) R. Rodolfo, et all., 2020

5. Disease Perception and Coping with Emotional Distress During COVID-19 Pandemic : A Survey Among Medical Staff (Romania) M. A. Melina, et all., 2020
Studi Cross-

Sectional

$\mathrm{N}=1729$

Perbedaan

individu: Khawatir apabila orang terdekat $\mathrm{S}=1711$ tenaga kesehatan di
Studi

Sectional

$\mathrm{N}=140$

responden

$\mathrm{S}=115$ tenaga

kesehatan di suatu

rumah sakit

\section{Cross- Perbedaan} individu: Persepsi tentang Covid-19.

Hasil analisis multiple regresi menunjukan bahwa anak tunggal dalam keluarga, dan anxiety merupakan faktor utama yang mempengaruhi stres pada perawat.

Tenaga kesehatan dilaporkan mengalami gangguan kesehatan mental akibat pandemic COVID19 seperti stres $(29.8 \%)$. Kerabat/ orang terdekat terpapar COVID19 merupakan salah satu faktor penyebab stres.

Tingkat stress tenaga kesehatan (skor 28) lebih tinggi dari kriteria tingkat stres orang China pada umumnya (skor 25/26). Faktor yang mempengaruhi stres pada tenaga kesehatan yaitu pengalaman kerja ( $>5$ tahun, 6-10 tahun, < 11 tahun).

Sebanyak 302 (21.90\%) tenaga kesehatan mengalami stres berat. Faktor yang menyebabkan stres kerja pada tenaga kesehatan adalah usia, berjenis kelamin perempuan, memiliki rekan yang dirawat dirumah sakit, dan memiliki rekan yang dikarantina.

Tenaga kesehatan memiliki tingkat stres sedang hingga tinggi selama beberapa minggu terakhir akibat banyaknya situasi berbahaya yang harus dihadapi. Semakin banyak pasien dengan penyakit katastropik, maka semakin tinggi tingkat stres tenaga kesehatan. Hal tersebut terjadi akibat adanya persepsi tenaga kesehatan bahwa pengobatan yang diberikan tidak dapat membantu penyembuhan 
Tabel 1. Matrix Literature Review (continued.)

\begin{tabular}{|c|c|c|c|c|}
\hline No. & $\begin{array}{c}\text { Judul, Peneliti, dan } \\
\text { Tahun }\end{array}$ & $\begin{array}{c}\text { Desain } \\
\text { Penelitian, } \\
\text { Populasi, dan } \\
\text { sampling }\end{array}$ & $\begin{array}{c}\text { Faktor penyebab } \\
\text { stres }\end{array}$ & Hasil \\
\hline
\end{tabular}

$\begin{array}{ll}\text { 6. } & \text { The Social } \\ & \text { Psychological } \\ \text { Impact of The } \\ \text { COVID-19 } \\ \text { Epidemic on } \\ \text { Medical Staff in } \\ \text { China: A Cross } \\ \text { Sectional Study } \\ \text { (China) D. Q. Zai, et } \\ \text { all., 2020 } \\ \text { Impact of COVID- } \\ \text { 19 on the Mental } \\ \text { Health of Healthcare } \\ \text { Professionals in } \\ \text { Pakistan (Pakistan) } \\ \text { S. Ram, et all., 2020 }\end{array}$

\begin{tabular}{|c|c|c|}
\hline $\begin{array}{l}\text { Studi Cross- } \\
\text { Sectional } \\
\mathrm{N}=4618 \text { tenaga } \\
\text { kesehatan di } 33 \\
\text { rumah sakit di } \\
\text { Provinsi Sichuan } \\
\text { dan Yunnan }\end{array}$ & $\begin{array}{l}\text { Perbedaan individu } \\
\text { : } \\
\text { Khawatir apabila } \\
\text { orang terdekat } \\
\text { terinfeksi COVID- } \\
19 .\end{array}$ & $\begin{array}{l}\text { Sebanyak } 24.2 \% \text { dari responden } \\
\text { mengalami gangguan emosional } \\
\text { semenjak pandemi COVID-19 } \\
\text { berlangsung. Tenaga kesehatan } \\
\text { yang khawatir dengan kesehatan } \\
\text { fisiknya dan memiliki keluarga } \\
\text { atau kerabat dekat terkena } \\
\text { COVID-19 berisiko memiliki } \\
\text { gangguan emosional. }\end{array}$ \\
\hline
\end{tabular}

$\mathrm{N}=112$ tenaga

kesehatan di

beberapa rumah sakit di Pakistan menginfeksi orang-

\section{Studi Cross- Sectional \\ $\mathrm{N}=111$ responden $\mathrm{S}=110$ tenaga kesehatan di University Hospital Ausburg}

professionals in

times of COVID-19

- a survey conducted at the University Hospital Augsburg (Jerman) Z. Giulia, et all., 2020

9. Resilience, COVID19-releted stress, anxiety, and depression during the pandemic in a large population enriched for healthcare providers (United States) B.

Ran, et all., 2020

10. Psychological effects of the COVID-2019 pandemic: perceived stress and coping strategies among healthcare

Studi Cross-

Sectional $\mathrm{N}=3042$ tenaga kesehatan

Studi CrossSectional $\mathrm{N}=595$ tenaga kesehatan pada beberapa wilayah terdampak professionals (Italia) B. Alessandra, et COVID-19 di Italia
Perbedaan

individu:

Khawatir orang terdekat

Secara keseluruhan terdapat 90.1\% (101 tenaga kesehatan) mengalami tingkat menengah hingga stres parah. Faktor penyebab stres dan anxiety tenaga kesehatan adalah khawatir akan menginfkesi virus pada keluarga mereka $(89.2 \%)$ dan khawatir akan terkena infeksi (80.3\%)

Perbedaan individu Rasa takut akan terinfeksi :

Kekhawatiran terinfeksi COVID19. COVID-19 berkolerasi positif terhadap depresi $\quad(\rho=0.28$, $\mathrm{p}=0.0035), \quad$ anxiety $\quad(\rho=0.27$, $p=0.0047)$, dan stres $(\rho=0.33$, $\mathrm{p}=0.0005)$.

Perbedaan individu: khawatir dapat menularkan Covid-19 pada orang terdekat

Partisipan merasa khawatir tentang keluarga yang positif COVID-19 atau tanpa diketahui menularkan COVID-19 kepada orang sekitar ( $\mathrm{t}$ F5,15205 = 1536.0, $\mathrm{p}<0.00001)$.

Perbedaan individu Rendahnya sikap positif dan : persepsi dan dukungan sosial tingginya dukungan sosial diprediksi dapat meningkatkan distress pada tenaga kesehatan akibat pandemi COVID-19. all., 2020 
Tabel 1. Matrix Literature Review (continued)

$\begin{array}{cccc}\text { No. Judul, Peneliti, dan } & \text { Desain } & \text { Faktor penyebab } & \text { Hasil } \\ \text { Tahun } & \text { Penelitian, } & \text { stres } \\ & \begin{array}{c}\text { Populasi, dan } \\ \text { sampling }\end{array} & \\ & & \end{array}$

\begin{tabular}{lll}
\hline 11. & Investigation of & Studi Cross- \\
adverse reaction in & Sectional \\
healthcare personnel & $\mathrm{N}=595$ tenaga \\
working in Level 3 & kesehatan pada \\
barrier protection & beberapa wilayah \\
PPE to treat & terdampak \\
COVID-19 (China) & COVID-19 di \\
Y. Niu, et all., 2020 & Italia
\end{tabular}

12. A qualitative study of Studi Kualitatif the vocational and $\mathrm{N}=25$ perawat psychological transdisipliner perceptions and 19 perawat nor

Perbedaan individu: pengalaman kerja issues of transdisipliner transdisciplinary nurses during the COVID-19 Outbreak (China)

Fan, et all., 2020

13. Depression, Anxiety, Stress levels of Psychians and associated factors in COVID-19 Pandemic (Turki) R. Y. Elbay, et all., 2020

14. Healthcare workers experience in dealing with Coronavirus (COVID-19) pandemic (Saudi Arabia) Almaghrabi H., et all. 2020

15. The Psychological Change Process of Frontline Nurses Caring for Patients with COVID-19 during Its Outbreak (China) Z. Yan, et all. 2020

16. Measuring the extent of stress and fear among Registered Nurses in KSA during the COVID19 Outbreak (Saudi Arabia) Tayyib, et all., 2020
Perbedaan individu: dukungan keluarga.

\section{Studi} CrossSectional $\mathrm{S}=442$ tenaga kesehatan di suatu rumah sakit

Studi Cross-
Sectional
$\mathrm{N}=1.036$ tenaga
kesehatan di
Prince Sultan
Military Medical
City

Studi Kualitatif Deskriptif

\section{Perbedaan individu:} $\mathrm{N}=23$ tenaga khawatir terinfeksi rumah sakit Wuhan

$\begin{array}{lll}\begin{array}{l}\text { Studi } \\ \text { Sectional }\end{array} & \text { Pross- } & \begin{array}{l}\text { Perbedaan } \\ \text { individu: persepsi }\end{array} \\ \mathrm{N}=314 & \text { tenaga } & \text { tentang } \text { COVID- } \\ \text { kesehatan } & \text { di } & 19 \\ \text { rumah sakit } & & \\ & & \end{array}$
kesehatan di COVID-19

Tenaga kesehatan junior (8.5 tahun bekerja) memiliki tingkat heatstress yang lebih tinggi dibandingkan tenaga kesehatan senior $(>8.5$ tahun bekerja $)(\chi 2=5.228, \mathrm{p}=0.022)$.

Hasil perhitungan PSS menunjukan bahwa perawat transdisipliner memiliki tingkat stres yang lebih tinggi dibandingkan perawat nondisipliner. Perawat transdisipliner memiliki dukungan sosial yang rendah daripada perawat nondisipliner. Kurangnya dukungan dari orang tua dan kekhawatiran akan kondisi keluaga merupakan penyebab umum terjadinya stres.

Sebanyak 182 partisipan $(41.2 \%)$ mengalami stres. Dukungan sosial dari atasan $(\mathrm{p}=.001)$ serta dukungan dari rekan kerja $(\mathrm{p}=.014)$ yang kurang menjadi faktor penyebab stres.

Sebanyak $77.8 \%$ partisipan berhenti bekerja selama masa pandemi, karena stres, seperti workload, persepsi tentang COVID-19, dan efek terhadap hubungan sosial .

Gangguan psikologi yang dialami oleh tenaga kesehatan terutama perawat dibagi menjadi tiga tahapan, tahap awal, tahap pertengahan, dan tahap lanjutan. Pada tahap awal tenaga kesehatan merasa bertanggung jawab untuk mengobati pasien COVID-19 dan merasa khawatir terinfeksi COVID-19.

Hasil menunjukan bahwa perawat secara umum memiliki tingkat anxiety dan stres yang tinggi selama pandemi COVID-19 (7.76 dari 10). Persepsi perawat mengenai stres akibat COVID-19 yang mereka alami menunjukan bahwa perawat berisiko tinggi untuk terkena infeksi selama menjalankan tugasnya. 


\section{Persepsi tentang COVID-19}

Persepsi tenaga kesehatan tentang COVID-19 menjadi salah satu faktor yang dapat meningkatkan stres kerja akibat pandemi COVID-19. Tenaga kesehatan memandang COVID-19 sebagai sesuatu hal yang negatif atau menakutkan, tidak dapat disembuhkan, dan dampak negatif yang dapat ditimbulkan dari persebaran COVID-19 bagi tenaga kesehatan (Almaghrabi et al., 2020; Babore et al., 2020; Man et al., 2020; Tayyib \& Alsolami, 2020)

\section{Pengalaman Kerja}

Stres dipengaruhi oleh pengalaman kerja seseoran (Xiao et al., 2020). Menurut Zhu et al., (2020) tenaga kesehatan dengan pengalaman kerja > 10 tahun berisiko memiliki tingkat stres yang lebih tinggi (Zhu et al., 2020). Sedangkan Yuan et al., (2020) melaporkan bahwa tenaga kesehatan dengan pengalaman bekerja 8.5 tahun mudah merasa stres saat menggunakan alat pelindung diri (APD) karena mengalami peningkatan suhu (heat stress) dibandingkan tenaga kesehatan yang bekerja > 8.5 tahun (Yuan et al., 2020)

\section{Kekhawatiran tentang COVID-19}

Faktor ini merupakan faktor penyebab utama stres yang paling sering dibahas dalam artikel/ jurnal rujukan. Tenaga kesehatan mengalami stres karena merasa khawatir akan wabah COVID-19 yang menyerang seluruh dunia (Mo et al., 2020). Perasaan khawatir ini disebabkan oleh berbagai macam alasan seperti, rasa khawatir/ takut apabila tanpa disengaja tenaga kesehatan telah menyebarkan viru kepada keluarga atau kerabat terdekat tenaga kesehatan khawatir/ takut terinfeksi COVID-19 saat melakukan perawatan kepada pasien positif COVID-19, dan tenaga kesehatan merasa khawatir/ takut ketika ada anggota keluarga atau orang terdekat positif COVID-19 (Barzilay et al., 2020; Dong et al., 2020; Rossi et al., 2020; Sandesh et al., 2020; Zerbini et al., 2020; Zhang et al., 2020; Zhu et al., 2020)

\section{Dukungan Sosial}

Saat mengemban tugasnya sebagai tenaga kesehatan dalam masa pandemi COVID-19 dukungan yang diberikan oleh orang-orang sekitar terutama keluarga, atasan, dan rekan kerja sangat dibutuhkan dan dapat meningkatkan semangat memberikan pelayanan bagi tenaga kesehatan (Elbay et al., 2020; Fan et al., 2020; Mo et al., 2020). Namun, pendapat lain dikemukakan oleh Babore et al., (2020) bahwa dukungan sosial yang tinggi dari keluarga justru menjadi salah satu faktor penyebab stres bagi tenaga kesehatan (Babore et al., 2020).

\section{Persepsi tentang COVID-19}

Babore et al., (2020) menemukan bahwa sikap positif merupakan faktor protektif yang paling kuat dalam melawan kesulitan (distress) yang dialami oleh tenaga kesehatan (Babore et al., 2020). Hal ini sejalan dengan penelitian terdahulu yang menyatakan bahwa sikap positif ditempat kerja merupakan strategi yang baik dalam mengurangi stres (Cai et al., 2020; Khalid et al., 2016). Tantangan yang dialami oleh tenaga kesehatan selama masa pandemi COVID-19, seperti kurangnya alat pelindung diri (APD), tempat kerja yang tidak nyaman, kondisi tempat kerja yang tidak sehat meningkatkan persepsi rasa takut bagi tenaga kesehatan apabila dapat menularkan virus pada keluarga. Hal tersebut bisa membuat tenaga kesehatan memiliki motivasi kerja yang rendah dan emosi negatif (Elbay et al., 2020).

Emosi negatif yang muncul pada tenaga kesehatan berupa persepsi bahwa penyakit COVID-19 ini sangat susah untuk disembuhkan dan tenaga kesehatan memiliki persepsi bahwa mereka tidak dapat mengendalikan penyakit COVID-19, sehingga tenaga kesehatan merasa stres (Man et al., 2020). Penelitian yang dilakukan oleh Almaghrabi et al., (2020) menunjukan bahwa sebanyak $77.8 \%$ tenaga kesehatan merasa stres dan memiliki keinginan untuk berhenti bekerja selama pandemi COVID19 berlangsung (Almaghrabi et al., 2020). Salah satu faktor yang mempengaruhi hal tersebut adalah adanya persepsi negatif pada tenaga kesehatan terkait tingkat kematian yang tinggi akibat COVID-19. Selain itu, Tayyib \& Alsolami (2020) mengemukakan bahwa tenaga kesehatan memiliki persepsi negatif berupa penempatan dirinya pada lingkungan yang berbahaya dapat membuat tenaga kesehatan mudah terinfeksi dan jatuh sakit (Tayyib \& Alsolami, 2020). Persepsi negatif yang muncul pada tenaga kesehatan akibat pandemi COVID19 dapat meningkatkan stres kerja karena tenaga kesehatan tidak dapat mengendalikan persepsi negatif yang muncul, sehingga tenaga kesehatan mudah jatuh sakit (Vagni et al., 2020).

\section{Pengalaman Kerja}

Zhu et al., (2020) melalui penelitiannya mengemukakan bahwa risiko anxiety, depresi, 
dan stres akan bertambah seiring dengan pertambahan pengalaman kerja. Tenaga kesehatan yang memiliki pengalaman kerja $>10$ tahun berisiko mengalami stres kerja karena kemungkinan tenaga kesehatan dengan pengalaman kerja yang lebih sedikit $(<2$ tahun) masih berstatus single, sehingga mereka tidak memiliki rasa tanggung jawab dalam hal berumah tangga dan mengalami kelelahan kerja yang lebih rendah dibandingkan dengan tenaga kesehatan yang memiliki pengalaman kerja $>10$ thaun (Zhu et al., 2020). Penelitian Yuan et al., (2020) melaporkan bahwa tenaga kesehatan dengan pengalaman bekerja 8.5 tahun mudah merasa stres saat menggunakan alat pelindung diri (APD) karena peningkatan suhu tubuh atau mengalami heatstress. Hal ini dikaitkan dengan pengalaman kerja tenaga kesehatan yang masih kurang terutama pengalaman mereka dalam menangani wabah seperti pandemi COVID-19 (Yuan et al., 2020).

Berdasarkan literatur tersebut dapat disimpulkan bahwa setiap pengalaman kerja memiliki tingkat stres yang berbeda. Tenaga kesehatan yang bekerja $>10$ tahun merasa stres karena memiliki tanggung jawab di rumah maupun di tempat kerja (Zhu et al., 2020). Sebaliknya, tenaga kesehatan dengan pengalaman kerja $<10$ tahun merasa stres ketika menggunakan APD karena kurangnya pelatihan menggunakan APD dalam melakukan pelayanan selama wabah terjadi (Yuan et al., 2020). Pengalaman kerja yang matang membuat tenaga kesehatan lebih percaya diri dalam menjalankan tugasnya, namun bukan berarti tekanan/ tuntutan yang diterima akan jauh lebih mudah dari sebelumnya.

\section{Kekhawatiran tentang COVID-19}

Mo et al., (2020) dalam penelitiannya menemukan bahwa anxiety/ rasa khawatir memiliki korelasi yang positif terhadap stres kerja. Semakin nyata perasaan khawatir yang dialami, maka semakin besar tekanan/ stres yang dirasakan oleh tenaga kesehatan (Mo et al., 2020). Khawatir tentang COVID-19 meliputi rasa khawatir apabila tenaga kesehatan terinfeksi COVID-19, khawatir dapat menularkan virus pada keluarga/ kerabat terdekat, serta rasa khawatir apabila keluarga/ kerabat terdekat terinfeksi COVID-19.

Penelitian yang dilakukan Zhu et al., (2020) menunjukan bahwa 158 tenaga kesehatan (3.1\%) diduga atau terinfeksi COVID-19 dan 70 orang $(44.3 \%)$ dari mereka memiliki anggota keluarga/ orang terdekat yang terinfeksi COVID-19. Secara umum sebesar 693 tenaga kesehatan $(15.1 \%)$ memiliki anggota keluarga yang diduga/ terinfeksi COVID-19 (Zhu et al., 2020). Tenaga kesehatan lebih mengkhawatirkan orang terdekat dapat terinfeksi COVID-19 alih-alih dirinya sendiri. Mengingat karakteristik transmisi penularan COVID-19 yang sangat cepat dan tenaga kesehatan bekerja pada tempat yang berbahaya membuat tenaga keehatan merasa khawatir/ takut dapat menularkan virus pada kerabat terdekat (Dong et al., 2020)

Zhang et al., (2020) membagi kelelahan emosional yang dialami oleh tenaga kesehatan pada 3 tahapan, yaitu tahap awal, tahap pertengahan, dan tahap akhir. Pada tahap awal inilah, tenaga kesehatan mudah merasa khawatir/ takut terkait COVID-19 yang penularannya sangat mudah dan cepat. Tenaga kesehatan merasa memiliki pengetahuan yang kurang terkait virus dan cara pengobatan virus, diikuti dengan angka kasus positif yang terus melonjak membuat mereka merasa khawatir akan dirinya dan kerabat terdekat (Zhang et al., 2020)

\section{Dukungan Sosial}

Penelitian yang dilakukan oleh Zerbini et al., (2020) menyatakan sebesar $37.5 \%$ tenaga kesehatan merasa sangat terbebani dengan pekerjaan yang dilakukannya saat masa pandemi. Ketika ditanya mengenai sumber daya terbesar bagi mereka dalam menghadapi pandemi COVID-19, sebesar $64.3 \%$ tenaga kesehatan menjawab dukungan sosial dari keluarga maupun dari teman sebagai penyemangat bagi tenga kesehatan (Zerbini et al., 2020). Namun, berbanding terbalik dengan penelitian Babore et al., (2020) yang menyatakan bahwa dukungan sosial yang tinggi justru menjadi faktor penyebab stres bagi tenaga kesehatan (Babore et al., 2020). Hal tersebut dapat diasumsikan bahwa dukungan sosial yang kuat justru menjadi beban tersendiri bagi tenaga kesehatan untuk mengupayakan pelayanan yang terbaik dalam situasi yang tidak pasti dan berbahaya bagi kesehatan serta keselamatannya.

Penelitian yang dilakukan oleh Fan, et al., (2020) menyatakan bahwa sebagian besar keluarga tenaga kesehatan tidak mengerti alasan mereka harus dikirim bekerja digaris depan (frontline) dalam upaya penanganan COVID-19. Selain itu, terdapat beberapa pasangan tenaga kesehatan yang bekerja untuk menangani 
COVID-19, mereka mengkhawatirkan keadaan anak mereka yang harus ditinggal untuk menjalankan tugas (Fan et al., 2020). Penelitian yang dilakukan oleh Mo et al., (2020) dalam penelitiannya menyatakan bahwa perawat yang merupakan anak tunggal dalam keluarga rentan mengalami stres kerja. Hal tersebut dikarenakan orang tua perawat merasa khawatir apabila harus kehilangan anak satu-satunya akibat COVID-19, sehingga keluarga memberi dukungan yang rendah bagi mereka (Mo et al., 2020)

Menurut Elbay et al., (2020) rendahnya dukungan atasan dan dukungan rekan kerja membuat tenaga kesehatan merasa stres (Elbay et al., 2020). Hal ini terjadi karena tenaga kesehatan membutuhkan seseorang yang bisa diajak bercerita mengenai permasalahan pribadinya maupun bertukar pikiran seputar masalah COVID-19, namun pada kenyataannya semua orang disibukan untuk memberi pelayanan terbaik terkait COVID-19 dan harus bekerja dengan waktu yang lebih lama, sehingga tidak mudah bagi mereka untuk saling bercerita selama menjalankan tugas atau disela-sela waktu istirahat. Selain itu, rekan kerja maupun atasan juga bisa dijadikan kekuatan selama jauh dari keluarga untuk saling memberi semangat dan dukungan mengingat keduanya juga berada dalam kondisi yang sama.

\section{KESIMPULAN DAN SARAN}

\section{Kesimpulan}

Masa pandemi COVID-19 merupakan masa yang sulit dan penuh penuh ketidakpastian tak terkecuali bagi tenaga kesehatan. Tenaga kesehatan berisiko mengalami stres kerja akibat tuntutan yang harus dihadapi selama pandemi COVID-19 berlangsung. Persepsi yang negatif terhadap COVID-19 dan pengalaman kerja yang kurang meningkatkan stres kerja pada kalangan tenaga kesehatan. Kekhawatiran tentang COVID-19 menjadi sumber utama individu berisiko tinggi mengalami stres. Tenaga kesehatan khawatir dapat menularkan virus kepada keluarga/ kerabat terdekat, keluarga/ kerabat terdekat terjangkit COVID-19, dan tenaga kesehatan positif COVID-19. Selain itu, dukungan sosial bagi tenaga kesehatan menjadi faktor yang dibutuhkan tenaga kesehatan untuk dapat menjalankan tugasnya secara optimal selama pandemi COVID-19.

\section{Saran}

Diharpkan tenaga kesehatan dapat menjaga kesehatan mentalnya selama bertugas untuk menangani pasien COVID-19 dengan cara berolahrga, bermeditasi, melakukan pengaturan napas, tetap menjalankan dan mematuhi protokol/ standar operasional prosedur (SOP) yang telah ditetapkan, mencari informasi terkait cara pengendalian COVID-19, serta membagi kisah kepada rekan kerja/ keluarga terkait kesulitan yang dihadapi.

\section{DAFTAR RUJUKAN}

1] Almaghrabi, R. H., Alfaradi, H., Hebshi, W. A. A., \& Albaadani, M. M. (2020). Healthcare workers experience in dealing with Coronavirus (COVID-19) pandemic. Saudi Medical Journal. https://doi.org/10.15537/SMJ.2020.6.2510 1

2] Babore, A., Lombardi, L., Viceconti, M. L., Pignataro, S., Marino, V., Crudele, M., Candelori, C., Bramanti, S. M., \& Trumello, C. (2020). Psychological effects of the COVID-2019 pandemic: Perceived stress and coping strategies among healthcare professionals. Psychiatry Research. https://doi.org/10.1016/j.psychres.2020.11 3366

3] Bai, Y. M., Lin, C. C., Lin, C. Y., Chen, J. Y., Chue, C. M., \& Chou, P. (2004). Survey of stress reactions among health care workers involved with the SARS outbreak. In Psychiatric Services. https://doi.org/10.1176/appi.ps.55.9.1055

4] Barzilay, R., Moore, T. M., Greenberg, D. M., DiDomenico, G. E., Brown, L. A., White, L. K., Gur, R. C., \& Gur, R. E. (2020). Resilience, COVID-19-related stress, anxiety and depression during the pandemic in a large population enriched for healthcare providers. Translational Psychiatry.

https://doi.org/10.1038/s41398-02000982-4

5] Cai, H., Tu, B., Ma, J., Chen, L., Fu, L., Jiang, Y., \& Zhuang, Q. (2020). Psychological impact and coping strategies of frontline medical staff in Hunan between 
January and March 2020 during the outbreak of coronavirus disease 2019 (COVID) in Hubei, China. Medical Science Monitor. https://doi.org/10.12659/MSM.924171

6] Catton, H. (2020). Global challenges in health and health care for nurses and midwives everywhere. International Nursing Review. https://doi.org/10.1111/inr.12578

7] Dong, Z.-Q., Ma, J., Hao, Y.-N., Shen, X.L., Liu, F., Gao, Y., \& Zhang, L. (2020). The social psychological impact of the COVID-19 pandemic on medical staff in China: A cross-sectional study. European Psychiatry. https://doi.org/10.1192/j.eurpsy.2020.59

8] Elbay, R. Y., Kurtulmuş, A., Arpacıoğlu, S., \& Karadere, E. (2020). Depression, anxiety, stress levels of physicians and associated factors in Covid-19 pandemics. Psychiatry Research. https://doi.org/10.1016/j.psychres.2020.11 3130

9] Fan, J., Hu, K., Li, X., Jiang, Y., Zhou, X., Gou, X., \& Li, X. (2020). A qualitative study of the vocational and psychological perceptions and issues of transdisciplinary nurses during the COVID-19 outbreak. Aging.

https://doi.org/10.18632/aging.103533

10] Green, B. N., Johnson, C. D., \& Adams, A. (2006). Writing narrative literature reviews for peer-reviewed journals: secrets of the trade. Journal of Chiropractic Medicine, 5(3). $\quad$ https://doi.org/10.1016/S08993467(07)60142-6

11] Greenberg, N., Docherty, M., Gnanapragasam, S., \& Wessely, S. (2020). Managing mental health challenges faced by healthcare workers during covid-19 pandemic. BMJ, 368 . https://doi.org/10.1136/bmj.m1211

12] Khalid, I., Khalid, T. J., Qabajah, M. R., Barnard, A. G., \& Qushmaq, I. A. (2016). Healthcare workers emotions, perceived stressors and coping strategies during a MERS-CoV outbreak. Clinical Medicine and Research. https://doi.org/10.3121/cmr.2016.1303

13] Liu, T., Hu, J., Xiao, J., He, G., Kang, M., Rong, Z., Lin, L., Zhong, H., Huang, Q.,
Zeng, S., Zhu, Z., Li, J., Gong, D., Wan, D., Chen, S., Guo, L., Li, Y., Sun, L., Liang, W., ... Ma, W. (2020). Time-varying dynamics of Novel Coronavirus Pneumonia in China. https://doi.org/https://doi.org/10.1101/202 0.01.25.919787

14] Man, M. A., Toma, C., Motoc, N. S., Necrelescu, O. L., Bondor, C. I., Chis, A. F., Lesan, A., Pop, C. M., Todea, D. A., Dantes, E., Puiu, R., \& Rajnoveanu, R. M. (2020). Disease perception and coping with emotional distress during covid-19 pandemic: A survey among medical staff. International Journal of Environmental Research and Public Health. https://doi.org/10.3390/ijerph17134899

15] Maunder, R. (2004). The experience of the 2003 SARS outbreak as a traumatic stress among frontline healthcare workers in Toronto: Lessons learned. Philosophical Transactions of the Royal Society B: Biological Sciences. https://doi.org/10.1098/rstb.2004.1483

16] Mo, Y., Deng, L., Zhang, L., Lang, Q., Liao, C., Wang, N., Qin, M., \& Huang, H. (2020). Work stress among Chinese nurses to support Wuhan in fighting against COVID-19 epidemic. Journal of Nursing Management. https://doi.org/10.1111/jonm.13014

17] National Health Commission of the People's Republic China. (2020). Prevention and Control Scheme of Novel Coronavirus. http://www.nhc.gov.cn/xcs/fkdt/202003/a 54a40ae28764f3581f36cc31204433c653f. shtml

18] Presiden RI. (2014). Undang-Undang RI Nomor 36 Tahun 2014 tentang Tenaga Kesehatan. In Presiden Republik Indonesia.

19] Que, J., Shi, L., Deng, J., Liu, J., Zhang, L., Wu, S., Gong, Y., Huang, W., Yuan, K., Yan, W., Sun, Y., Ran, M., \& Bao, Y. (2020). Psychological impact of the COVID-19 pandemic on healthcare workers: a cross-sectional study in China. General Psychiatry, 33. https://doi.org/10.1136/gpsych-2020100259

20] Robbins, S. P., \& Judge, T. A. (2013). Organizational Behavior (S. Yagan (ed.); 
15th ed.). Pearson Eucation, Inc.,.

21] Rossi, R., Socci, V., Pacitti, F., Di Lorenzo, G., Di Marco, A., Siracusano, A., \& Rossi, A. (2020). Mental Health Outcomes Among Frontline and Second-Line Health Care Workers During the Coronavirus Disease 2019 (COVID-19) Pandemic in Italy. JAMA Network Open. https://doi.org/10.1001/jamanetworkopen. 2020.10185

22] Sandesh, R., Shahid, W., Dev, K., Mandhan, N., Shankar, P., Shaikh, A., \& Rizwan, A. (2020). Impact of COVID-19 on the Mental Health of Healthcare Professionals in Pakistan. Cureus. https://doi.org/10.7759/cureus.8974

23] Shereen, M., Khan, S., Kazmi, A., Bashir, N., \& Siddique, R. (2020). Infection: Origin, Transmission, and Characteristics of Human Coronaviruses. Journal of Advanced Research, 24, 91-98. https://doi.org/10.1016/j.jare.2020.03.005

24] Smith, J., \& Firth, J. (2011). Qualitative data analysis: the framework approach. Nurse Researcher, 18(2), 52-62. https://doi.org/10.7748/nr2011.01.18.2.52. c8284

25] Tayyib, N. A., \& Alsolami, F. J. (2020). Measuring the extent of stress and fear among Registered Nurses in KSA during the COVID-19 Outbreak. Journal of Taibah University Medical Sciences. https://doi.org/10.1016/j.jtumed.2020.07.0 12

26] Vagni, M., Maiorano, T., Giostra, V., \& Pajardi, D. (2020). Hardiness, stress and secondary trauma in Italian healthcare and emergency workers during the COVID-19 pandemic. Sustainability (Switzerland). https://doi.org/10.3390/su12145592

WHO. (2020). Coronavirus disease
(COVID-19) pandemic. WHO. https://www.who.int/emergencies/diseases /novel-coronavirus-2019

28] Xiao, X., Zhu, X., Fu, S., Hu, Y., Li, X., \& Xiao, J. (2020). Psychological impact of healthcare workers in China during COVID-19 pneumonia epidemic: A multicenter cross-sectional survey investigation. Journal of Affective Disorders. https://doi.org/10.1016/j.jad.2020.05.081

29] Yuan, N., Yang, W. X., Lu, J. L., \& Lv, Z. H. (2020). Investigation of adverse reactions in healthcare personnel working in Level 3 barrier protection PPE to treat COVID-19. Postgraduate Medical Journal.

https://doi.org/10.1136/postgradmedj2020-137854

30] Zerbini, G., Ebigbo, A., Reicherts, P., Kunz, M., \& Messman, H. (2020). Psychosocial burden of healthcare professionals in times of covid-19 - a survey conducted at the university hospital augsburg. GMS German Medical Science. https://doi.org/10.3205/000281

31] Zhang, Y., Wei, L., Li, H., Pan, Y., Wang, J., Li, Q., Wu, Q., \& Wei, H. (2020). The Psychological Change Process of Frontline Nurses Caring for Patients with COVID-19 during Its Outbreak. Issues in Mental Health Nursing. https://doi.org/10.1080/01612840.2020.17 52865

32] Zhu, Z., Xu, S., Wang, H., Liu, Z., Wu, J., Li, G., Miao, J., Zhang, C., Yang, Y., Sun, W., Zhu, S., Fan, Y., Hu, J., Liu, J., \& Wang, W. (2020). COVID-19 in Wuhan: Immediate psychological impact on 5062 Health Workers. In medRxiv. https://doi.org/10.1101/2020.02.20.20025 338 